\title{
Potential Risks and Benefits of Multiple Sclerosis Immune Therapies in the COVID-19 Era: Clinical and Immunological Perspectives
}

\author{
Vikram Bhise $^{1}$ (D) $\cdot$ Suhayl Dhib-Jalbut ${ }^{2}$ \\ Accepted: 11 January 2021 / Published online: 2 February 2021 \\ (C) The American Society for Experimental NeuroTherapeutics, Inc. 2021
}

\begin{abstract}
Coronavirus SARS-CoV2 has emerged as one of the greatest infectious disease health challenges in a century. Patients with multiple sclerosis (MS) have a particular vulnerability to infections through their use of immunosuppressive disease-modifying therapies (DMTs). Specific DMTs pose particular risk based on their mechanisms of action (MOA). As a result, patients require individualized approaches to starting new treatments and continuation of therapy. Additionally, vaccinations must be considered carefully, and individuals on long-term B cell-depleting therapies may have diminished immune responses to vaccination, based on preserved $\mathrm{T}$ cells and diminished but present antibody titers to influenza vaccines. We review the immunology behind these treatments and their impact on COVID-19, as well as the current recommendations for best practices for use of DMTs in patients with MS.
\end{abstract}

Key Words Multiple sclerosis $\cdot$ SARS-CoV2 $\cdot$ disease-modifying therapy $\cdot$ vaccination $\cdot$ COVID- $19 \cdot$ immunology

\section{Introduction}

In November 2019, the world community was exposed to one of the most challenging infectious diseases in a generationCOVID-19 caused by coronavirus SARS-CoV-2 [1]. Patients with multiple sclerosis (MS) were immediately recognized as a vulnerable population due to the unique combination of immunosuppressive therapies they require. Given the high infectivity rates and incidence of SARS-CoV-2, practitioners were suddenly faced with difficult questions about continuation or interruption of therapy. The prevailing concern has been that immunosuppression through DMT usage increases the risk of infection. On the other hand, some of these treatments may be unexpectedly protective by limiting the effects of auto-inflammation and the cytokine storm seen in severe COVID-19 cases.

Vikram Bhise

bhisevi@rwjms.rutgers.edu

1 Departments of Pediatrics, Rutgers Robert Wood Johnson Medical School, 89 French Street, Suite 2200, New Brunswick, NJ 08901, USA

2 Department of Neurology, Rutgers Robert Wood Johnson Medical School, 125 Paterson Street, Suite 65000, New Brunswick, NJ 08901, USA

\section{Clinical Considerations}

\section{Treatment Risks}

Initial smaller studies suggested neither an increase in risk of infection nor an increased rate of hospitalization for patients with MS [2]. Case reports of small numbers of subjects treated with dimethyl fumarate [3] or teriflunomide $[4,5]$ described good outcomes and even hypothesized potentially protective roles for these treatments based on their mechanisms of action. Case reports on fingolimod [5-7] and ocrelizumab or rituximab [8-10] initially appeared to be reassuring as well.

However, although overall disease-modifying therapies appear relatively safe in aggregate $[2,11,12]$, there may be concerns related to individual strategies based on newer data. For example, patients on B cell-depleting therapies, such as rituximab, ocrelizumab, and alemtuzumab, may not be as adept at developing protective IgM and IgG antibodies [13-15] and are thus at higher risk of infection [11]. Case studies have demonstrated those infected with SARS-CoV-2 while on B cell-depleting therapies can, nevertheless, recover despite the illness, affirming that innate and/or cell-mediated protective mechanisms against the virus remain viable [16-18]. However, more recent worldwide data have indicated an increased risk of serious infections for patients on these therapies $[19,20]$. These concerns include higher rates of hospital 
admissions, intensive care unit admissions, and requirements for mechanical ventilation, but not death, possibly more so for rituximab compared to ocrelizumab [21]. These findings did not appear to be affected by the duration of therapy for ocrelizumab in post-marketing data [22]. An excellent article by Baker et al. [23] reviews B cell therapies in greater detail. Furthermore, a large European prospective cohort study (RADAR-CNS) identified a trend for increased risk of SARS-CoV-2 infection in those on alemtuzumab or cladribine, though these agents did not appear to affect infection severity [24].

Currently, studies are underway collecting data on greater numbers of patients with SARS CoV-2 infection. These cohorts are not yet large enough to make specific conclusions for patients with MS. Notably, the MS population is significantly different from the general population in that they are more likely to have comorbid health issues, including those already identified to put people at risk, such as diabetes, cardiopulmonary disease, and obesity [25]. Interestingly, some studies have suggested that those not on MS therapy may be at higher risk of severe illness from SARS CoV-2 [22, 25], though this may be driven by older patients who are less likely to be on treatment or other confounding factors. Furthermore, risks for worse outcomes appear to be not limited only to relapsing MS patients, but also to those with progressive forms of the disease [19].

Despite reasonable concerns, most practitioners generally do not recommend discontinuation of immunomodulatory therapy [26]. The decision to start MS therapy is not made lightly and, therefore, neither is the decision to continue. Patients who self-discontinue, may in certain instances put themselves at risk of disease rebound, namely with natalizumab or fingolimod [26]. In general, the injectable therapies, glatiramer acetate and the beta-interferons, as well as teriflunomide, dimethyl fumarate, and prednisone formulations, are not believed to increase the risk of immunosuppression significantly. Treatments with a mildly elevated risk include fingolimod, natalizumab, ocrelizumab, and rituximab. More careful consideration should be taken for employing higher potency therapies such as cladribine and alemtuzumab [26]. While these may be maintained, they ought not to be initiated during the pandemic. In fact, the risk for viral infection may be higher at the 3- to 6-month timeframe after starting cladribine or alemtuzumab [27].

Several studies have even suggested that immunomodulatory/immunosuppressive therapies may in fact be protective against the hyper-inflammatory phase of SARSCoV-2 infection by preventing the release of proinflammatory cytokines or B cell activity [17] [27]. This may be particularly true for agents such as fingolimod and siponimod, which work through the RhoA/actin pathway and reduce recruitment of macrophages to pulmonary tissue [28].
One must also balance the risk of hospitalization for an MS relapse due to withdrawing therapy with the risk of exposure to SARS-CoV-2 from attending infusion centers or any monitoring required therewith for surveillance [29]. Fortunately, some infusions can be given at patients' homes, and more exceptions or modifications have been allowed during the pandemic by companies offering infusions for treatments traditionally limited to infusion centers. While posing a higher risk, medications with infrequent delivery, such as the B celldepleting therapies given on average every 6 months, still present a favorable option. Ofatumumab offers a novel alternative for $\mathrm{B}$ cell depletion through monthly subcutaneous injections. The need for frequent monitoring with alemtuzumab, an anti-CD52 therapy administered intravenously, on the other hand, may be an excessive burden.

\section{Treatment Modifications}

Current strategies among practitioners include extending the time interval between infusion-based treatments when possible [30]. For example, every 4 -week dosing of natalizumab can be extended to every 6-week dosing, based on data suggesting decreased risks of developing progressive multifocal leukoencephalopathy but similar rates of efficacy [31, 32]. And the second alemtuzumab treatment, normally given at 12 months, may be delayed up to 18 months [33]. One may consider switching to another disease-modifying therapy instead of proceeding to subsequent rounds of treatment with alemtuzumab or cladribine following induction. Ocrelizumab and rituximab infusions may also be delayed for certain patients based on serial monthly CD20/CD19 counts [34], although this must be weighed against the risk of exposure to SARS-CoV-2 from having more frequent phlebotomies. In many instances, B cell-depleting therapies provide therapeutic immunosuppression far longer than the standard 6 months, potentially as long as 12 months or more.

Corticosteroids are also generally believed to reduce the robustness of the immune response, and increase the chances of developing an infection in individuals on long-term immunosuppressive therapy [35]. However, in cases of severe SARS-CoV-2 infection, notably with an excessive autoinflammatory response, well-timed and judicious use of lowdose therapy may be beneficial, possibly also in treating individuals with severe respiratory disease requiring oxygen or mechanical ventilation [36-38]. Nevertheless, IVIg and plasma exchange stand as viable alternatives for treatment of an MS relapse to avoid the immunosuppressive effects of steroids.

In terms of the risk of MS therapies during this pandemic from least to most favorable, the following ranking should be considered: alemtuzumab-cladribine-ocrelizumab/rituximab-fingolimod-and then all others [39] (see Table 1). Thakolwiboon et al. [40] summarize recommendations by 
European neurological associations based on risk and mechanism of action. In individuals with active COVID-19, it is advised to defer therapy until symptoms abate [40]. This may not be necessary for the platform therapies, namely glatiramer acetate or interferon, especially for the latter which may have protective properties [19]. These speculations remain hypothetical, however, as little confirmatory data is available comparing continued versus deferred therapy during hospitalization.

\section{The Immune Response to SARS-CoV-2}

SARS-CoV-2 is an enveloped single-stranded RNA virus capable of infecting cells in several human organs including the lung epithelium, gastrointestinal tract, heart, kidneys, and the central nervous system [41-43]. ACE-2 expressed on the surface of target cells is the binding receptor for the virus spike (S) protein $[44,45]$. This binding results in ACE-2 cleavage from cell surfaces by ADAM metallopeptidase domain 17 (ADAM17). Reduction in ACE-2 levels increases angiotensin II levels leading to increased vascular permeability [46]. ADAM17 converts membrane IL-6 receptor to a soluble form (sIL-6Ra), which forms complexes with IL-6, resulting in the activation of STAT3 and the NF-kB inflammatory pathway [47]. The invading virus then replicates intracellularly and is released and recognized by pattern recognition receptors (PRPs), Toll-like receptors (TLR), and others on dendritic cells resulting in the activation of innate immune responses. Dendritic cells and subsequently infiltrating macrophages [48, 49] release a myriad of proinflammatory molecules including interleukins, type-1 interferon, chemokines, TNF $\alpha, \mathrm{TGF} \beta$, and free radicals, which while fighting the virus can also overreact, resulting in a cytokine storm and multisystem organ failure (Fig. 1). The adaptive immune response also comes into play. Helper CD4+, cytotoxic CD8+, and NK cells are activated and play a role in limiting the infection [47].
Cytotoxic CD8+ cells directly kill virus-infected cells. Helper CD4+ cells activate B cells to produce anti-viral IgG and IgM which bind to the virus spike protein and along with complement components $\mathrm{C} 1 \mathrm{q}, \mathrm{r}, \mathrm{s}$ and $\mathrm{C} 3 \mathrm{~b}$ play a role in opsonization and neutralization of the virus. On the other hand, activation of the lectin pathway through the binding of mannose-binding lectin (MBL) to the spike protein ultimately leads to the formation of the membrane attack complex (C5b9) and tissue damage [50]. Notably, the virus can lead to immunosuppression by killing infected lymphocytes [51].

\section{Chronic Immunomodulation/Immunosuppression and COVID-19}

There are nine classes of FDA-approved therapies for MS and three therapies for neuromyelitis optica spectrum disorder (NMOSD) [52] (Table 2). In general, prior to initiating MS therapies, COVID-19 testing is recommended to exclude asymptomatic infection that may become symptomatic upon initiation of immune therapies. For acute MS exacerbations, short-term corticosteroids, IVIg, and plasma exchange are unlikely to increase significantly the risk of infection with SARS-CoV-2 [53]. Low-dose corticosteroid therapy may, in fact, be beneficial in acute respiratory distress syndrome (ARDS) secondary to COVID-19 [54].

In general, MS patients are not at higher risk for contracting COVID-19 as far as the disease itself is concerned, but they could be at higher risk for worse outcomes if exposed to the virus while on immunosuppressive therapy. As with other infections, patients may experience an MS relapse or a pseudo-relapse. COVID-19 course and outcome will also be influenced by the type of MS therapy the patient is receiving, whether the drug is immunomodulatory or immunosuppressive, and whether it has anti-viral effects such as interferon- $\beta$ $($ IFN $\beta$ ) and possibly teriflunomide. In general,
Table 1 Stratification of MS disease modifying treatment plans during the COVID-19 pandemic

\begin{tabular}{llll}
\hline Medication & Risk & Currently receiving & New start \\
\hline Interferon $\beta$ & Lowest & Continue & Yes* \\
Glatiramer acetate & Lowest & Continue & Yes \\
Dimethyl or diroximel fumarate & Low & Continue & Yes \\
Teriflunomide & Low & Continue & Yes \\
Fingolimod/siponimod/ozanimod & Medium & Continue & Yes \\
Natalizumab & Medium & Extend to 6-week intervals & Yes \\
Rituximab/ocrelizumab/ofatumumab & Medium-high & Extend interval based on B cell counts & Yes \\
Cladribine & High & Delay/switch & No** \\
Alemtuzumab & High & Delay/switch & No \\
Hematopoietic stem cell therapy & High & Delay/switch & No \\
\hline
\end{tabular}

*Yes: treatment can be initiated; **No: postpone treatment 


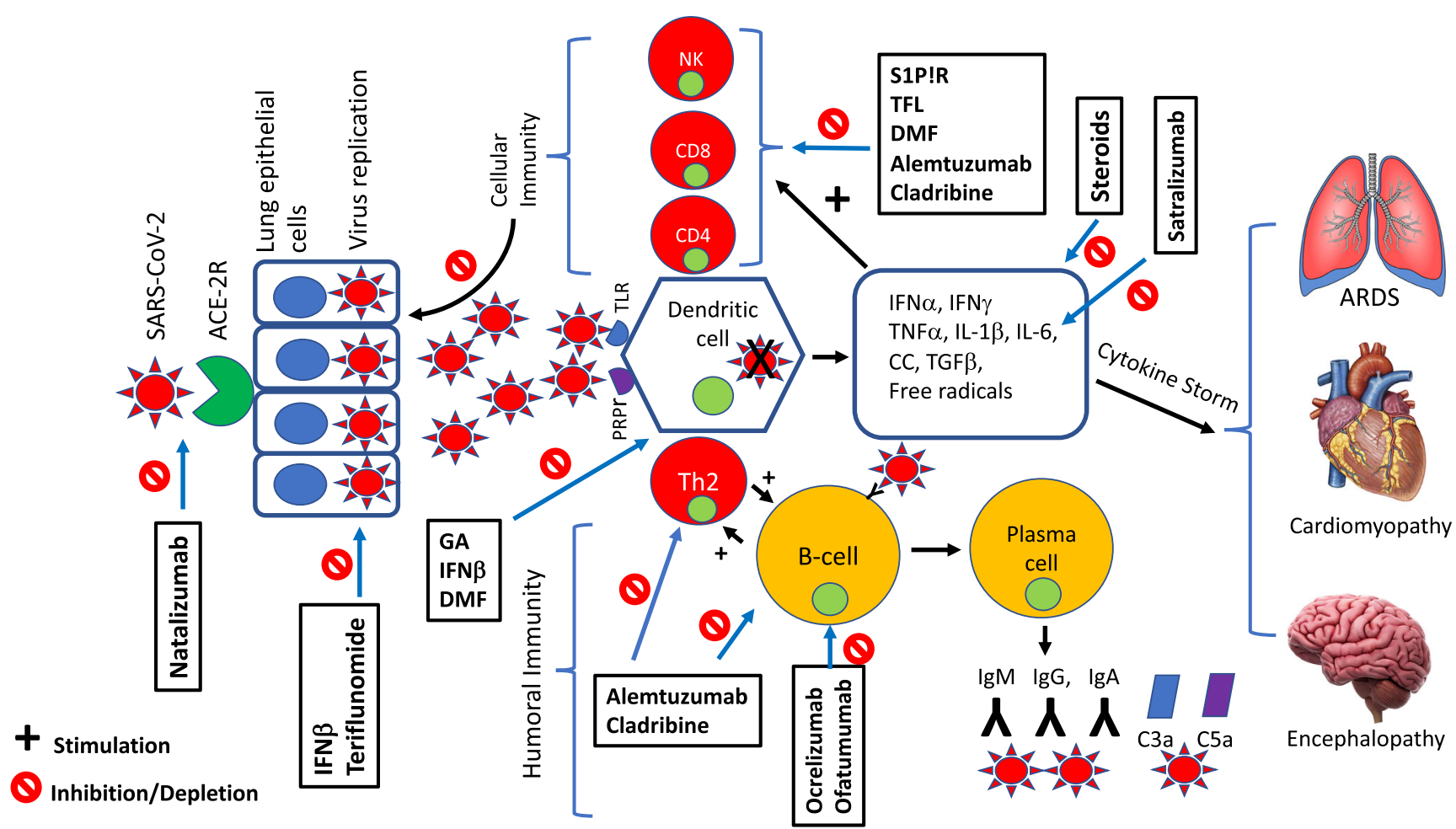

Fig. 1 The immune response to SARS-CoV-2 and potential sites of interaction with MS therapies. The virus binds to the angiotensinconverting enzyme-2 receptor (ACE-2R) on lung epithelial cells allowing cell entry, viral replication, and shedding. It interacts with lung dendritic cells through pattern recognition receptors (PRPs) and Toll-like receptors (TLRs) leading to the upregulation of proinflammatory cytokines, chemokines, and free radicals. An over-reactive immune response results in the "cytokine storm" that leads to the acute respiratory distress syndrome (ARDS), cardiomyopathy, and potentially encephalopathy. Both

immunomodulatory agents such as IFN $\beta$, glatiramer acetate, and dimethyl fumarate are less likely to affect adversely the course of COVID-19 as long as significant lymphopenia is not present [55]. Conceptually, these three drugs can be beneficial in COVID-19 by modulating different aspects of the immune response to the virus. For example, IFN $\beta$ enhances NK cellmediated cytotoxicity, antibody-dependent cytotoxicity, and phagocytosis [56], and inhibits viral replication [57]. Most concerning are immunosuppressive drugs that deplete $\mathrm{T}$ cells, B cells, or both such as alemtuzumab, ocrelizumab, ofatumumab, and cladribine. These agents may weaken cellular and humoral immune responses to the virus by eliminating cytotoxic $\mathrm{T}$ cells and antibody-producing plasma cells. Therapy that sequesters lymphocytes in lymphoid tissue such as the sphingosine-1 phosphate receptor (S1PR) modulator family of drugs (fingolimod and siponimod among others) causes significant leukopenia and may increase the risk for worse outcomes. Therapy-induced lymphopenia can be compounded by the fact that SARS-CoV-2 infects leukocytes triggering apoptosis, which correlates with a worsened disease course [58]. Then again, S1P1R modulation may mitigate acute pulmonary injury through increased endothelial cell cellular (helper T cells, cytotoxic T cells, NK cells, and dendritic cells) and humoral (antibody-producing plasma cells and complement) immune responses are deployed to control the virus. MS therapies can potentially influence the immune response to the infection in beneficial or potentially harmful ways depending on whether the therapy is immunomodulatory (GA, IFN $\beta, D M F$ ) or immunosuppressive (alemtuzumab, ocrelizumab, ofatumumab, and teriflunomide). Some may also have anti-viral effects (IFN $\beta$ and teriflunomide)

integrity and reduced vascular permeability [59]. Natalizumab, which reduces trafficking of immune cells into the brain, may impair viral clearance from the CNS; this is troubling especially since SARS-CoV-2 may infect the CNS [43]. On the other hand, natalizumab can be beneficial by interfering with virus binding to the ACE- 2 receptor. The site of action of MS therapies and their potential interference with the immune response to SARS-CoV-2 are shown in Fig. 1.

\section{Immune Response to Anticipated COVID-19 Vaccines in the Context of MS Therapies}

Several vaccines against SARS-CoV-2 are currently in clinical trials, with two approved for use in the USA at the time of this publication $[60,61]$. These include the use of recombinant viral vectors as delivery vehicles, attenuated live virus, inactivated virus, and RNA-based vaccines that feature the spike protein of the virus [62]. While live vaccines can conceivably increase the risk of an MS relapse, inactivated vaccines, such as influenza, are generally safe. The two currently approved COVID-19 vaccines do not include the virus itself, 
Table 2 Potential impact of MS therapies on COVID-19 clinical course

\begin{tabular}{|c|c|c|c|c|}
\hline MS medication & MOA & Potential benefit in COVID-19 & Potential adverse effect in COVID-19 & References \\
\hline Interferon $\beta$ & $\begin{array}{l}\text { Immunomodulatory; } \\
\text { Anti-viral }\end{array}$ & $\begin{array}{l}\text { Reduced viral replication; } \\
\text { inhibition of proinflammatory } \\
\text { cytokines }\end{array}$ & Unknown & [69] \\
\hline $\begin{array}{l}\text { Glatiramer } \\
\text { acetate }\end{array}$ & Enhances Th2 and Treg cells & $\begin{array}{l}\text { Counteract proinflammatory } \\
\text { responses }\end{array}$ & Unknown & [70] \\
\hline Natalizumab & $\begin{array}{l}\text { Blocks } \alpha 4 \text {-integrin on immune cells } \\
\text { and trafficking across BBB }\end{array}$ & $\begin{array}{l}\text { May interfere with } \\
\text { SARS-CoV-2 host cell entry }\end{array}$ & $\begin{array}{l}\text { Reduced SARS-CoV-2 clearance } \\
\text { from the CNS and gut }\end{array}$ & {$[71,72]$} \\
\hline S1PR modulators & Traps lymphocytes in lymphoid tissue & $\begin{array}{l}\text { Lymphopenia may be beneficial } \\
\text { for pneumonia and ARDS }\end{array}$ & $\begin{array}{l}\text { Lymphopenia resulting in reduced } \\
\text { viral clearance }\end{array}$ & {$[73]$} \\
\hline $\begin{array}{l}\text { Dimethyl } \\
\text { fumarate } \\
\text { (DMF) }\end{array}$ & $\begin{array}{l}\text { Nrf2-mediated anti-oxidative stress; cy- } \\
\text { tokine modulation }\end{array}$ & $\begin{array}{l}\text { Reduced innate immune } \\
\text { response to virus }\end{array}$ & $\begin{array}{l}\text { Lymphopenia-related increased risk } \\
\text { of infection and impaired viral } \\
\text { clearance }\end{array}$ & [74] \\
\hline Teriflunomide & $\begin{array}{l}\text { Inhibits de novo pyrimidine synthesis; } \\
\text { cytostatic; inhibits viral replication }\end{array}$ & Anti-viral effect & $\begin{array}{l}\text { Lymphopenia-related increased risk } \\
\text { of infection and impaired viral } \\
\text { clearance }\end{array}$ & {$[75]$} \\
\hline $\begin{array}{l}\text { B cell-depleting } \\
\text { agents } \\
\text { (anti-CD20) }\end{array}$ & $\begin{array}{l}\text { Decreased antigen presentation, } \\
\text { inflammatory cytokines, and } \\
\text { antibody production }\end{array}$ & Unknown & $\begin{array}{l}\text { Increased risk of infection and } \\
\text { impaired viral clearance }\end{array}$ & {$[76,77]$} \\
\hline Cladribine & $\begin{array}{l}\text { Purine analogue that results in } \mathrm{T} \text { and } \mathrm{B} \\
\text { cells depletion }\end{array}$ & Unknown & $\begin{array}{l}\text { Lymphopenia-related increased risk } \\
\text { of infection and impaired viral } \\
\text { clearance }\end{array}$ & {$[78]$} \\
\hline $\begin{array}{l}\text { Alemtuzumab } \\
\text { (anti-CD52) }\end{array}$ & $\begin{array}{l}\mathrm{T} \text { and B cell depletion; enhanced Treg } \\
\text { cells }\end{array}$ & Unknown & $\begin{array}{l}\text { Lymphopenia-related increased risk } \\
\text { of infection and impaired viral } \\
\text { clearance }\end{array}$ & [79] \\
\hline $\begin{array}{l}\text { Satralizumab } \\
\text { (anti-IL6 in } \\
\text { NMOSD*) }\end{array}$ & $\begin{array}{l}\text { Inhibition of B cell differentiation and } \\
\text { IL-17 }\end{array}$ & $\begin{array}{l}\text { Reduced impact of cytokine } \\
\text { storm }\end{array}$ & Unknown & $\begin{array}{l}\text { Kleiter, I. et al. } \\
\text { MS Virtual } \\
2020\end{array}$ \\
\hline Eculizumab & Complement $\mathrm{C} 5$ inhibitor & Reduced tissue damage & Unknown & {$[80]$} \\
\hline
\end{tabular}

$A R D S$ acute respiratory distress syndrome, $B B B$ blood-brain barrier, $M O A$ mechanism of action, $N M O S D$ neuromyelitis optica spectrum disorder, $N r f-2$ nuclear factor erythroid 2-related factor-2, SIPR sphingosine-1 phosphate receptor, Treg regulatory T cells

only the instructions to generate a target viral-type protein against which an immune response can be generated [63]. While these vaccines contain no adjuvant, they may hypothetically signal TLR and lipid particles may be immunostimulatory, or be taken up by macrophages in turn releasing pro-inflammatory cytokines. These processes could contribute to the short-term side effects of the vaccine. The safety of the anticipated COVID-19 vaccines remains to be established in vulnerable populations especially those with autoimmune conditions such as MS. With the anticipated development and availability of effective and safe vaccines against COVID-19, the question is how effective the vaccine will be in generating protective immunity in patients on immunomodulatory or immunosuppressive therapies. This is likely to depend on the mechanism of action of the MS therapy and timing of the vaccine relative to the treatment cycle. Based on experience with other vaccines in MS-treated patients, therapies that do not deplete or suppress immune cells are less likely to interfere with vaccine efficacy, whereas those that deplete T cells, B cells, or both could interfere with vaccine efficacy, especially if the timing of the vaccine relative to the treatment cycle is not optimal [64]. For example, in the case of the B cell-depleting therapy ocrelizumab, which is typically administered on a 6-month interval schedule, it would make sense to administer the vaccine toward the end of the cycle and 1 month before the next cycle. Given the need for a booster injection for the currently approved vaccinations at day 21 or 28 after the first vaccine dose, additional time may be required for plasma cell or memory B cell development in secondary lymphoid organs which would require delaying the ocrelizumab dose by $4-6$ weeks $[65,66]$. In the case of the newer monthly administered subcutaneous B cell-depleting therapy ofatumumab, vaccinations could be delivered toward the end of the monthly cycle and the next two ofatumumab doses skipped to allow for the booster vaccine to take effect. In certain cases, therapy interruption may be necessary [23]. Serological monitoring of humoral and cellular immune responses to the vaccine would be instructive under such circumstances. The specific choice of therapy may also affect the duration of B cell depletion. Memory B cell repletion can take up to 18 months after discontinuation of ocrelizumab, but up to 11-12 months for rituximab and ofatumumab [23]. Moreover, the presence of worsening IgA and IgM hypogammaglobinemia with repeated infusions in some 
patients may lead to suboptimal serological responses in those individuals on prolonged therapy $[67,68]$. Possible solutions may include additional booster vaccinations or utilizing more than one vaccine formulation for patients demonstrating insufficient SARS-CoV-2 post-vaccination antibody responses. Ciotti et al. provide an excellent review of data on vaccination responses to various MS DMTs, identifying potential impairments in all but the interferons [64]. With additional information gleaned from future studies, we hope to gain better insight about the safety profiles specific to each DMT and best strategies for vaccination.

\section{Future Considerations}

As MS registries across the world are increasingly recording and reporting on COVID-19 cases, important knowledge will be gained about the demographics and risk factors that affect COVID-19 outcomes in the MS population, which immunomodulatory and immunosuppressive therapies increase the risk of contracting COVID-19, and which therapies are potentially beneficial especially in patients with ARDS. As vaccines against COVID-19 become available, choosing a safe vaccine that does not increase the risk of MS relapses is critical. Additionally, timing vaccine delivery relative to receiving immunosuppressive therapy, and analyzing the humoral and cellular immune responses to the vaccine will inform optimal vaccine delivery.

Funding Vikram Bhise-Dr. Bhise serves on the Biogen Data Safety Monitoring Board.

Suhayl Dhib-Jalbut-Dr. Dhib-Jalbut received consultant fees from Biogen, Genzyme, and Genentech.

\section{References}

1. Huang C, Wang Y, Li X, Ren L, Zhao J, Hu Y, et al. Clinical features of patients infected with 2019 novel coronavirus in Wuhan, China. Lancet. 2020;395(10223):497-506.

2. Parrotta E, Kister I, Charvet L, Sammarco C, Saha V, Charlson RE, et al. COVID-19 outcomes in MS: Observational study of early experience from NYU Multiple Sclerosis Comprehensive Care Center. Neurology(R) neuroimmunology \& neuroinflammation. 2020;7(5).

3. Mantero V, Abate L, Basilico P, Balgera R, Salmaggi A, Nourbakhsh B, et al. COVID-19 in dimethyl fumarate-treated patients with multiple sclerosis. Journal of neurology. 2020:1-3.

4. Maghzi AH, Houtchens MK, Preziosa P, Ionete C, Beretich BD, Stankiewicz JM, et al. COVID-19 in teriflunomide-treated patients with multiple sclerosis. Journal of neurology. 2020;267(10):27906.

5. Bollo L, Guerra T, Bavaro DF, Monno L, Saracino A, Angarano G, et al. Seroconversion and indolent course of COVID-19 in patients with multiple sclerosis treated with fingolimod and teriflunomide. Journal of the neurological sciences. 2020;416:117011.
6. Barzegar M, Mirmosayyeb O, Nehzat N, Sarrafi R, Khorvash F, Maghzi AH, et al. COVID-19 infection in a patient with multiple sclerosis treated with fingolimod. Neurology(R) neuroimmunology \& neuroinflammation. 2020;7(4).

7. Foerch C, Friedauer L, Bauer B, Wolf T, Adam EH. Severe COVID-19 infection in a patient with multiple sclerosis treated with fingolimod. Mult Scler Relat Disord. 2020;42:102180.

8. Suwanwongse K, Shabarek N. Benign course of COVID-19 in a multiple sclerosis patient treated with Ocrelizumab. Mult Scler Relat Disord. 2020;42:102201.

9. Ghajarzadeh M, Mirmosayyeb O, Barzegar M, Nehzat N, Vaheb S, Shaygannejad V, et al. Favorable outcome after COVID-19 infection in a multiple sclerosis patient initiated on ocrelizumab during the pandemic. Mult Scler Relat Disord. 2020;43:102222.

10. Montero-Escribano P, Matías-Guiu J, Gómez-Iglesias P, PortaEtessam J, Pytel V, Matias-Guiu JA. Anti-CD20 and COVID-19 in multiple sclerosis and related disorders: A case series of 60 patients from Madrid, Spain. Mult Scler Relat Disord. 2020;42: 102185 .

11. Loonstra FC, Hoitsma E, van Kempen ZL, Killestein J, Mostert JP. COVID-19 in multiple sclerosis: The Dutch experience. Multiple sclerosis (Houndmills, Basingstoke, England). 2020;26(10):125660 .

12. Hughes R, Pedotti R, Koendgen H. COVID-19 in persons with multiple sclerosis treated with ocrelizumab - A pharmacovigilance case series. Mult Scler Relat Disord. 2020;42:102192.

13. Meca-Lallana V, Aguirre C, Beatrizdel R, Cardeñoso L, Alarcon T, Vivancos J. COVID-19 in 7 multiple sclerosis patients in treatment with ANTI-CD20 therapies. Mult Scler Relat Disord. 2020;44: 102306.

14. Thornton JR, Harel A. Negative SARS-CoV-2 antibody testing following COVID-19 infection in Two MS patients treated with ocrelizumab. Mult Scler Relat Disord. 2020;44:102341.

15. Bar-Or A, Calabresi PA, Arnold D, Markowitz C, Shafer S, Kasper LH, et al. Rituximab in relapsing-remitting multiple sclerosis: a 72week, open-label, phase I trial. Annals of neurology. 2008;63(3): 395-400.

16. Woo MS, Steins D, Häußler V, Kohsar M, Haag F, Elias-Hamp B, et al. Control of SARS-CoV-2 infection in rituximab-treated neuroimmunological patients. Journal of neurology. 2020:1-3.

17. Novi G, Mikulska M, Briano F, Toscanini F, Tazza F, Uccelli A, et al. COVID-19 in a MS patient treated with ocrelizumab: does immunosuppression have a protective role? Mult Scler Relat Disord. 2020;42:102120.

18. Sabatino JJ, Jr., Wilson MR, Calabresi PA, Hauser SL, Schneck JP, Zamvil SS. Anti-CD20 therapy depletes activated myelin-specific CD8(+) T cells in multiple sclerosis. Proceedings of the National Academy of Sciences of the United States of America. 2019;116(51):25800-7.

19. Sormani MPaDR, Nicola and Schiavetti, Irene and Carmisciano, Luca and Cordioli, Cinzia and Moiola, Lucia and Radaelli, Marta and Immovilli, Paolo and Capobianco, Marco and Trojano, Maria and Zaratin, Paola and Tedeschi, Gioacchino and Comi, Giancarlo and Battaglia, Mario Alberto and Patti, Francesco and Salvetti, Marco and Group, Musc-19 Study. Disease Modifying Therapies and COVID-19 Severity in Multiple Sclerosis Lancet. 2020.

20. Safavi F, Nourbakhsh B, Azimi AR. B-cell depleting therapies may affect susceptibility to acute respiratory illness among patients with multiple sclerosis during the early COVID-19 epidemic in Iran. Mult Scler Relat Disord. 2020;43:102195.

21. Simpson-Yap S, editor First results of COVID-19 and MS Global Data Sharing Initiative suggest anti-CD20 DMTs are associated with worse COVID-19 outcomes. MS Virtual 2020 8th Joint ACTRIMS-ECTRIMS meeting; 2020 09/26/2020.

22. R. Hughes KF, L. Whitley, N Jessop, HM Schneble, E. Muros-Le Rouzic, A Sauter, R. Pedotti, H Koendgen, editor COVID-19 in 
Persons with Multiple Sclerosis Treated with Ocrelizumab: Pharmacal Vigilance Update. MS Virtual 2020 8th Joint ACTRIMS-ECTRIMS meeting; 2020 09/26/2020.

23. Baker D, Roberts CAK, Pryce G, Kang AS, Marta M, Reyes S, et al. COVID-19 vaccine-readiness for anti-CD20-depleting therapy in autoimmune diseases. Clinical and experimental immunology. 2020

24. Dalla Costa G, Leocani L, Montalban X, Guerrero AI, Sørensen PS, Magyari M, et al. Real-time assessment of COVID-19 prevalence among multiple sclerosis patients: a multicenter European study. Neurological sciences : official journal of the Italian Neurological Society and of the Italian Society of Clinical Neurophysiology. 2020;41(7):1647-50.

25. Louapre C, Collongues N, Stankoff B, Giannesini C, Papeix C, Bensa C, et al. Clinical Characteristics and Outcomes in Patients With Coronavirus Disease 2019 and Multiple Sclerosis. JAMA neurology. 2020;77(9):1079-88.

26. Hartung HP, Aktas O. COVID-19 and management of neuroimmunological disorders. Nature reviews Neurology. 2020;16(7):347-8.

27. Giovannoni G. Anti-CD20 immunosuppressive disease-modifying therapies and COVID-19. Mult Scler Relat Disord. 2020;41: 102135.

28. Kloc M, Ghobrial RM. The multiple sclerosis (MS) drugs as a potential treatment of ARDS in COVID-19 patients. Mult Scler Relat Disord. 2020;45:102437.

29. Baker D, Amor S, Kang AS, Schmierer K, Giovannoni G. The underpinning biology relating to multiple sclerosis disease modifying treatments during the COVID-19 pandemic. Mult Scler Relat Disord. 2020;43:102174.

30. Moss BP, Mahajan KR, Bermel RA, Hellisz K, Hua LH, Hudec T, et al. Multiple sclerosis management during the COVID-19 pandemic. Multiple sclerosis (Houndmills, Basingstoke, England). 2020;26(10):1163-71.

31. Ryerson LZ, Foley J, Chang I, Kister I, Cutter G, Metzger RR, et al. Risk of natalizumab-associated PML in patients with MS is reduced with extended interval dosing. Neurology. 2019;93(15):e1452-e62.

32. Chang I, Muralidharan KK, Campbell N, Ho PR. Modeling the Efficacy of Natalizumab in Multiple Sclerosis Patients Who Switch From Every-4-Week Dosing to Extended-Interval Dosing. Journal of clinical pharmacology. 2020.

33. Coles AJ, Cox A, Le Page E, Jones J, Trip SA, Deans J, et al. The window of therapeutic opportunity in multiple sclerosis: evidence from monoclonal antibody therapy. Journal of neurology. 2006;253(1):98-108

34. Giovannoni G, Hawkes C, Lechner-Scott J, Levy M, Waubant E, Gold J. The COVID-19 pandemic and the use of MS diseasemodifying therapies. Mult Scler Relat Disord. 2020;39:102073.

35. Youssef J, Novosad SA, Winthrop KL. Infection Risk and Safety of Corticosteroid Use. Rheumatic diseases clinics of North America. 2016;42(1):157-76, ix-x.

36. Qin YY, Zhou YH, Lu YQ, Sun F, Yang S, Harypursat V, et al. Effectiveness of glucocorticoid therapy in patients with severe coronavirus disease 2019: protocol of a randomized controlled trial. Chinese medical journal. 2020;133(9):1080-6.

37. Kory P, Kanne JP. SARS-CoV-2 organising pneumonia: 'Has there been a widespread failure to identify and treat this prevalent condition in COVID-19?'. BMJ open respiratory research. 2020;7(1).

38. Alijotas-Reig J, Esteve-Valverde E, Belizna C, Selva-O'Callaghan A, Pardos-Gea J, Quintana A, et al. Immunomodulatory therapy for the management of severe COVID-19. Beyond the anti-viral therapy: A comprehensive review. Autoimmunity reviews. 2020;19(7): 102569.

39. Zheng C, Kar I, Chen CK, Sau C, Woodson S, Serra A, et al. Multiple Sclerosis Disease-Modifying Therapy and the COVID-
19 Pandemic: Implications on the Risk of Infection and Future Vaccination. CNS drugs. 2020;34(9):879-96.

40. Thakolwiboon S, Zhao-Fleming H, Pan J, Scott JK, Shoji E, Sohn $\mathrm{G}$, et al. Disease-Modifying Therapies During the COVID-19 Outbreak: A Narrative Review of International and National Recommendations. International journal of MS care. 2020;22(4): 151-7.

41. Zou L, Ruan F, Huang M, Liang L, Huang H, Hong Z, et al. SARSCoV-2 Viral Load in Upper Respiratory Specimens of Infected Patients. The New England journal of medicine. 2020;382(12): 1177-9.

42. Wichmann D, Sperhake JP, Lütgehetmann M, Steurer S, Edler C, Heinemann A, et al. Autopsy Findings and Venous Thromboembolism in Patients With COVID-19: A Prospective Cohort Study. Annals of internal medicine. 2020;173(4):268-77.

43. Matschke J, Lütgehetmann M, Hagel C, Sperhake JP, Schröder AS, Edler C, et al. Neuropathology of patients with COVID-19 in Germany: a post-mortem case series. The Lancet Neurology. 2020;19(11):919-29.

44. Sungnak W, Huang N, Bécavin C, Berg M, Queen R, Litvinukova $\mathrm{M}$, et al. SARS-CoV-2 entry factors are highly expressed in nasal epithelial cells together with innate immune genes. Nature medicine. 2020;26(5):681-7.

45. Xu X, Chen P, Wang J, Feng J, Zhou H, Li X, et al. Evolution of the novel coronavirus from the ongoing Wuhan outbreak and modeling of its spike protein for risk of human transmission. Science China Life sciences. 2020;63(3):457-60.

46. Ni W, Yang X, Yang D, Bao J, Li R, Xiao Y, et al. Role of angiotensin-converting enzyme 2 (ACE2) in COVID-19. Critical care (London, England). 2020;24(1):422.

47. Mortaz E, Tabarsi P, Varahram M, Folkerts G, Adcock IM. The Immune Response and Immunopathology of COVID-19. Frontiers in immunology. 2020;11:2037.

48. McGonagle D, Sharif K, O'Regan A, Bridgewood C. The Role of Cytokines including Interleukin-6 in COVID-19 induced Pneumonia and Macrophage Activation Syndrome-Like Disease. Autoimmunity reviews. 2020;19(6):102537.

49. Merad M, Martin JC. Pathological inflammation in patients with COVID-19: a key role for monocytes and macrophages. Nature reviews Immunology. 2020;20(6):355-62.

50. Noris M, Benigni A, Remuzzi G. The case of complement activation in COVID-19 multiorgan impact. Kidney international. 2020;98(2):314-22.

51. Blanco-Melo D, Nilsson-Payant BE, Liu WC, Uhl S, Hoagland D, Møller R, et al. Imbalanced Host Response to SARS-CoV-2 Drives Development of COVID-19. Cell. 2020;181(5):1036-45.e9.

52. Comi G, Dalla Costa G, Moiola L. Newly approved agents for relapsing remitting multiple sclerosis: how real-world evidence compares with randomized clinical trials? Expert review of neurotherapeutics. 2020:1-14.

53. Korsukewitz C, Reddel SW, Bar-Or A, Wiendl H. Neurological immunotherapy in the era of COVID-19 - looking for consensus in the literature. Nature reviews Neurology. 2020;16(9):493-505.

54. Alhazzani W, Møller MH, Arabi YM, Loeb M, Gong MN, Fan E, et al. Surviving Sepsis Campaign: Guidelines on the Management of Critically Ill Adults with Coronavirus Disease 2019 (COVID19). Critical care medicine. 2020;48(6):e440-e69.

55. Schreiber G. The Role of Type I Interferons in the Pathogenesis and Treatment of COVID-19. Frontiers in immunology. 2020;11: 595739

56. Dhib-Jalbut S. Mechanisms of interferon beta action in multiple sclerosis. Multiple sclerosis (Houndmills, Basingstoke, England). 1997;3(6):397-401.

57. Mark DF, Lu SD, Creasey AA, Yamamoto R, Lin LS. Site-specific mutagenesis of the human fibroblast interferon gene. Proceedings 
of the National Academy of Sciences of the United States of America. 1984;81(18):5662-6.

58. Yang X, Yu Y, Xu J, Shu H, Xia J, Liu H, et al. Clinical course and outcomes of critically ill patients with SARS-CoV-2 pneumonia in Wuhan, China: a single-centered, retrospective, observational study. The Lancet Respiratory medicine. 2020;8(5):475-81.

59. Natarajan V, Dudek SM, Jacobson JR, Moreno-Vinasco L, Huang LS, Abassi T, et al. Sphingosine-1-phosphate, FTY720, and sphingosine-1-phosphate receptors in the pathobiology of acute lung injury. American journal of respiratory cell and molecular biology. 2013;49(1):6-17.

60. Polack FP, Thomas SJ, Kitchin N, Absalon J, Gurtman A, Lockhart S, et al. Safety and Efficacy of the BNT162b2 mRNA Covid-19 Vaccine. The New England journal of medicine. 2020.

61. Jackson LA, Anderson EJ, Rouphael NG, Roberts PC, Makhene M, Coler RN, et al. An mRNA Vaccine against SARS-CoV-2 Preliminary Report. The New England journal of medicine. 2020;383(20):1920-31.

62. Jeyanathan M, Afkhami S, Smaill F, Miller MS, Lichty BD, Xing Z. Immunological considerations for COVID-19 vaccine strategies. Nature reviews Immunology. 2020;20(10):615-32.

63. Sharma O, Sultan AA, Ding H, Triggle CR. A Review of the Progress and Challenges of Developing a Vaccine for COVID-19. Frontiers in immunology. 2020;11:585354.

64. Ciotti JR, Valtcheva MV, Cross AH. Effects of MS diseasemodifying therapies on responses to vaccinations: A review. Mult Scler Relat Disord. 2020;45:102439.

65. Davis CW, Jackson KJL, McCausland MM, Darce J, Chang C, Linderman SL, et al. Influenza vaccine-induced human bone marrow plasma cells decline within a year after vaccination. Science (New York, NY). 2020;370(6513):237-41.

66. Wrammert J, Smith K, Miller J, Langley WA, Kokko K, Larsen C, et al. Rapid cloning of high-affinity human monoclonal antibodies against influenza virus. Nature. 2008;453(7195):667-71.

67. Conte WL. Attenuation of antibody response to SARS-CoV-2 in a patient on ocrelizumab with hypogammaglobulinemia. Mult Scler Relat Disord. 2020;44:102315.

68. Marcinnò A, Marnetto F, Valentino P, Martire S, Balbo A, Drago A, et al. Rituximab-induced hypogammaglobulinemia in patients with neuromyelitis optica spectrum disorders. Neurology(R) neuroimmunology \& neuroinflammation. 2018;5(6):e498.

69. Dhib-Jalbut S, Marks S. Interferon-beta mechanisms of action in multiple sclerosis. Neurology. 2010;74 Suppl 1:S17-24.
70. Dhib-Jalbut S. Mechanisms of action of interferons and glatiramer acetate in multiple sclerosis. Neurology. 2002;58(8 Suppl 4):S3-9.

71. Niino M, Bodner C, Simard ML, Alatab S, Gano D, Kim HJ, et al. Natalizumab effects on immune cell responses in multiple sclerosis. Annals of neurology. 2006;59(5):748-54.

72. Sigrist CJ, Bridge A, Le Mercier P. A potential role for integrins in host cell entry by SARS-CoV-2. Antiviral research. 2020;177: 104759.

73. Cross AH, Naismith RT. Established and novel disease-modifying treatments in multiple sclerosis. Journal of internal medicine. 2014;275(4):350-63.

74. Li R, Rezk A, Ghadiri M, Luessi F, Zipp F, Li H, et al. Dimethyl Fumarate Treatment Mediates an Anti-Inflammatory Shift in B Cell Subsets of Patients with Multiple Sclerosis. Journal of immunology (Baltimore, Md : 1950). 2017;198(2):691-8.

75. Bar-Or A. Teriflunomide (Aubagio $®$ ) for the treatment of multiple sclerosis. Experimental neurology. 2014;262 Pt A:57-65.

76. Hauser SL, Bar-Or A, Comi G, Giovannoni G, Hartung HP, Hemmer B, et al. Ocrelizumab versus Interferon Beta-1a in Relapsing Multiple Sclerosis. The New England journal of medicine. 2017;376(3):221-34.

77. Bar-Or A, Grove RA, Austin DJ, Tolson JM, VanMeter SA, Lewis EW, et al. Subcutaneous ofatumumab in patients with relapsingremitting multiple sclerosis: The MIRROR study. Neurology. 2018;90(20):e1805-e14.

78. Giovannoni G. Cladribine to Treat Relapsing Forms of Multiple Sclerosis. Neurotherapeutics : the journal of the American Society for Experimental NeuroTherapeutics. 2017;14(4):874-87.

79. Wiendl H, Carraro M, Comi G, Izquierdo G, Kim HJ, Sharrack B, et al. Lymphocyte pharmacodynamics are not associated with autoimmunity or efficacy after alemtuzumab. Neurology(R) neuroimmunology \& neuroinflammation. 2020;7(1).

80. Diurno F, Numis FG, Porta G, Cirillo F, Maddaluno S, Ragozzino A, et al. Eculizumab treatment in patients with COVID-19: preliminary results from real life ASL Napoli 2 Nord experience. European review for medical and pharmacological sciences. 2020;24(7):4040-7.

Publisher's Note Springer Nature remains neutral with regard to jurisdictional claims in published maps and institutional affiliations. 